\title{
Environmental Awareness, Concern, Attitude and Behavior of University Students: A Comparison Across Academic Disciplines
}

\author{
Hafiz Muhammad Arshad ${ }^{1 *}$, Khalid Saleem², Sajida Shafi², \\ Tanvir Ahmad ${ }^{3}$, Sumaira Kanwal ${ }^{1}$ \\ ${ }^{1}$ COMSATS University Islamabad, Sahiwal Campus, Sahiwal, Pakistan \\ ${ }^{2}$ University of Okara, Okara, Pakistan \\ ${ }^{3}$ Government College University, Faisalabad, Pakistan
}

Received: 20 March 2020

Accepted: 19 May 2020

\begin{abstract}
Environmental issues such as global warming, air pollution and ozone depletion have become global challenges. However, environmental awareness, environmental concern, environmental attitude and environmental behavior of individuals, as well as their academic background knowledge, are potential factors that may help in coping with these challenges. Here, we evaluated environmentalawareness, concern, attitude and behavior of university students across the five academic disciplines including arts \& humanities, social sciences, physical sciences, biological sciences and environmental sciences. Further, we investigated how environmental- awareness, concern, and attitude influence the environmental behavior of individuals. Data was collected from 824 students of two public and two private sector universities through a self-administered questionnaire. The level of environmental awareness, environmental concern and environmental behavior of university students were found significantly high, whereas, level of environmental attitude was significantly low. Levels of environmental awareness, environmental concern and environmental behavior for all the five disciplines were found adequately high, but the level of environmental attitude was high for only two groups, i.e. physical sciences and biological sciences, and, low for three other groups. The group of biological sciences was ranked at top in all the four cases of awareness, concern, attitude and behavior. Moreover, the effects of environmental awareness and environmental concern on environmental behavior were found significantly positive, whereas the effect of environmental attitude was significantly negative.
\end{abstract}

Keywords: environmental awareness, environmental concern, environmental attitude, environmental behavior; environmental issues, academic disciplines

*e-mail: hmarshadphd@gmail.com hmarshadphd@cuisahiwal.edu.pk 


\section{Introduction}

Environmental pollution is a serious concern for better life and sustainable use of resources [1, 2]. Rapid development in urbanization, industrialization and agriculture has caused increased exploitation of natural resources and environmental pollution. Environmental degradation has several human and ecological consequences [3-5]. Of these, human health is considered a serious global concern. For instance, environmental pollution may cause ailment to lungs, kidney, liver, heart and several other health disorders [6-9]. A systematic review showed that, in 2012, 23\% of global deaths were attributable to the environment [10]. Similarly, environmental pollution may affect at any level of ecology such as individuals, populations, communities or ecosystems and biospheres. Ecological effects include habitat fragmentation, functional disorders, population decline, extinction of species and many more [11-14]. According to an estimate, water bodies within $40 \%$ of the global land surface are at risk of insecticide pollution [15]. Thus, aquatic ecosystem may be affected in terms of structure and function [5, 16-18], and decline and extinction of different species $[19,20]$. Additionally, environmental degradation can influence the economic situation of a country. Although environmental restoration is expensive [21, 22], it is very important to avoid such drastic consequences, especially for third world countries.

Most of the anthropogenic environmental fluctuations can be managed by changing the relevant behavior of individuals. Positive changes in human behavior patterns are desired for nature conservation. For instance, pro-environment people may use recyclable and reusable products, water-saving devices, energy-efficient appliances and ultimately can minimize environmental destruction [23]. They can also benefit the environment or even try to less harm the environment [24]. Hence, pro-environmental behavior is a major factor that can abate environmental issues. Environmental awareness, environmental concern, and environmental attitude are three major influential factors that can help in improving the environmental behavior of people $[25,26]$.

Environmental awareness is an educational tool that helps people to understand the aesthetic, biological and economic importance of preserving the natural resources and minimizing the negative effects of man-made adaptations and alterations [27-29]. Several studies have reported a low level of environmental awareness and negative attitude among the students, teachers and other groups of society [30, 31]. Even sometimes those students are found with low levels of environmental awareness and/or environemental behavior who have attended several courses relating to environmental issues [32]. But high level of environmental awareness among individuals influences positively in developing the responsible environmental behavior $[25,33]$
Environmental attitude means affective beliefs of individuals regarding participation in activities that can improve the environment, their competence on environmental improvement and values toward the natural environment [34]. Positive environmental attitude creates responsible environmental behavior among people [26, 35, 36]. Boiyo, Koech [37] reported the positive impact of environmental attidue on behaviour of university students. Lo-Iacono-Ferreira, Bahr [38] reported that the environmental attitude of individual students significantly effects the collective environmental performance of their university. Huang and Yore [39] have reported that environmental attitude has a significant effect on environmental concern and improves environmental behavior ultimately. Kaiser, Wölfing [40] have also reported a signigicant relationship between environmental attitude and environmental behavior of individuals by considering the situations when it becomes out of control to behave ecologically. Environmental concern is another important factor that may develop pro-environmental behavior in people [41]. It involves the sensitivity of individuals toward existing environmental conditions and crises [42, 43]. McKenzieMohr, Nemiroff [44] have reported significantly higher environmental concerns among environmental activists than non-activists. Wong [45] has reported high consciousness of Chinese university students about the environmental issues being faced by the people at the country and global levels.

Since public initiatives are essential for effective environmental protection, we designed this study to investigate pro-environmental behavior and associated factors among university students. No study has investigated yet, the differences of environmentalawareness, attitude, concern and behavior among the students of different academic disciplines. Thus, to fill this gap, this study has evaluated and compared the environmental- awareness, attitude, concern and behavior of university studenta across five academic disciplines viz; arts \& humanities, social sciences, physical sciences, biological sciences and environmental sciences. Moreover, the impacts of environmental awareness, environmental attitude and environmental concern of university students have also been investigated on their environmental behavior.

\section{Materials and Methods}

Data was collected through survey questionnaire method. For this purpose, four public and private sector universities (two from each) were selected. University students were divided into five major academic disciplines i.e. arts \& humanities, social sciences, physical sciences (mathematics-based), biological sciences, and environmental sciences. It was a quantitative research with deductive approach and positivism research philosophy. An online sample size calculator [46] suggested a sample size of 381 with 
a $5 \%$ margin of error and a $95 \%$ confidence interval, however, in order to enhance the adequacy of results, the data was collected from 824 students. Before including in the sample, a verbal consent was obtained from each participant. Only those students were included in the sample who participated willingly. All the research ethics like integrity, dignity and privacy of participants, confidentiality of data and anonymity of results were ensured throughout the research process.

\section{Instrumentation}

In the present study, four latent variables viz; environmental awareness, environmental concern, environmental attitude, and environmental behavior have been studied. Different scales were employed to measure these variables. Environmental awareness was measured through the perception of individuals about their awareness level regarding the environmental issues being faced by the global world. Students were asked to select one of the five choices ranging from 1 to 5 as $1=$ no information, 2 = little information, 3 = medium level information, $4=$ sufficient information, and $5=$ complete information. The list of major

Table 1. List of environmental issues.

\begin{tabular}{|c|c|}
\hline $\begin{array}{l}\text { Serial } \\
\text { No. }\end{array}$ & Name of Issue \\
\hline 1. & Climate Change \\
\hline 2. & Depletion of ozone layer \\
\hline 3. & Air pollution \\
\hline 4. & Quality of drinking water \\
\hline 5. & Global Warming \\
\hline 6. & Polar Melt \\
\hline 7. & Motor vehicle pollution \\
\hline 8. & Industrial pollution \\
\hline 9. & Food contamination by Pesticides \\
\hline 10. & $\begin{array}{l}\text { Food contamination by growth hormones and } \\
\text { antibiotics }\end{array}$ \\
\hline 11. & Bio-Engineered food supply \\
\hline 12. & Electromagnetics (power lines, cell phones, etc.) \\
\hline 13. & Pollution of rivers and oceans \\
\hline 14. & Flooding \\
\hline 15. & Littering \\
\hline 16. & Poor waste management (e.g. overuse of landfills) \\
\hline 17. & Using up the earth's resources \\
\hline 18. & Extinction of species \\
\hline 19. & Radioactive waste \\
\hline 20. & Overpopulation (of the earth by humans) \\
\hline
\end{tabular}

environmental issues, extracted from international environmental standards and other literature is presented in Table 1 [47-49]. Similarly, the concern of the students toward these issues was also measured with the help of their own perception. They were asked to select any one of the five choices ranging from 1 to 5 i.e. $1=$ no concern, $2=$ low concern, $3=$ medium concern, $4=$ high concern, and $5=$ very high concern.

The scale for measuring the environmental attitude of university students was adapted from Huang and Yore [39]. It consisted of 8 items of five points Likert type. The sample items are "My efforts to improve our environment are useful" and "It is hopeful to repair the damaged environment no matter how small I try". The students were asked to select any one of the five choices ranging from "strongly disagree" to "strongly agree". Similarly, the scale for measuring the environmental behavior of university students was also adapted from Huang and Yore [39]. This scale consisted of 12 items of Likert type. The respondents were asked to rank their behavior (oral or physical actions) by selecting any one of the five choices ranging from "I have never done" to "I have always done". The sample questions are "How often did you recycle trash?" and "How often did you buy environment friendly products and also suggest your family?".

\section{Data Analysis Techniques}

The statistical software SPSS was used for data analysis. To measure the level of environmental awareness, environmental concern, environmental attitude, and environmental behavior, descriptive statistics were applied. For comparison of different influential variables among the academic disciplines, one-way ANOVA was conducted. In order to measure the effects of environmental awareness, environmental concern and environmental attitude on environmental behavior, multiple regression was applied through OLS method. The applied multiple regression equation is:

$$
E B=\beta_{0}+\beta_{1}(E A)+\beta_{2}(E C)+\beta_{3}(E a t t)+\varepsilon
$$

...where $E B$ is the Environmental Behavior, $E A$ is Environmental Awareness, $E C$ is Environmental Concern, Eatt is Environmental Attitude and $\varepsilon$ is random error. Before conducting regression analysis, normality of the dependent variable and the multicollinearity of the independent variables were also studied. Both assumptions were found satisfactory.

\section{Results}

We investigated environmental awareness, environmental concern, environmental attitude and environmental behavior among university students using questionnaire method. In total, 824 students from different disciplines viz; arts \& humanities 
(18\%), social sciences $(27 \%)$, physical sciences $(30 \%)$, biological sciences $(15 \%)$ and environmental sciences $(10 \%)$ responded to the questionnaire. The majority of the students $(85 \%)$ were 17 to 24 years old.

\section{Environmental Awareness of University Students}

To measure environmental awareness among university students, we gathered their responses to 20 different environmental issues. Mean awareness of 6 environmental issues i.e. polar melt (2.59), bio-engineered food supply (2.66), littering (2.82), extinction of species (2.85), radioactive waste (2.90) and food contamination by growth hormones (2.92) were ranked as below medium level (Fig. 1). Awareness regarding all other environmental issues except air pollution (4.1, above sufficient level) ranged from medium to sufficient level. Grand mean of the environmental awareness among the university students 3.30 was significantly higher than the mean of the scale i.e. medium level awareness (one-sample t-test; $t=13.39, p$-value $=0.000)$. Environmental awareness across academic disciplines was significantly different (ANOVA; $\mathrm{F}=20.12, p$-value $=0.000)$. The students of biological sciences showed the highest awareness (mean 3.69), followed by environmental sciences (mean 3.42), arts \& humanities (mean 3.33), physical sciences (mean 3.24) and social sciences (mean 3.09).

\section{Environmental Concern of University Students}

Environmental concern is another important factor that may influence the development of positive behavior among individuals regarding environmental issues. The mean environmental concern of the university students for air pollution, quality of drinking water, motor vehicle pollution, industrial pollution, and overpopulation was ranked as high concern, whereas, for others, it was above medium level (Fig. 2). Grand mean of the environmental concern among university students 3.86 was significantly higher than mean of the scale 3 i.e. medium level concern (one-sample t-test; $t=39.504, p$-value $=0.000)$. Environmental concern across academic disciplines was significantly different (ANOVA; F $=11.36$, $p$-value $=0.000$ ). The students of biological sciences showed the highest concern (mean 4.14), followed by environmental sciences (mean 3.94), arts \& humanities and physical sciences (mean 3.85), and social sciences (mean 3.69).

\section{Environmental Attitude of University Students}

The environmental attitude of an individual has vital importance with respect to the development of environmental behavior. The attitude of the students has been measured with the help of a scale consisting of the eight items. Students were given 5 choices for

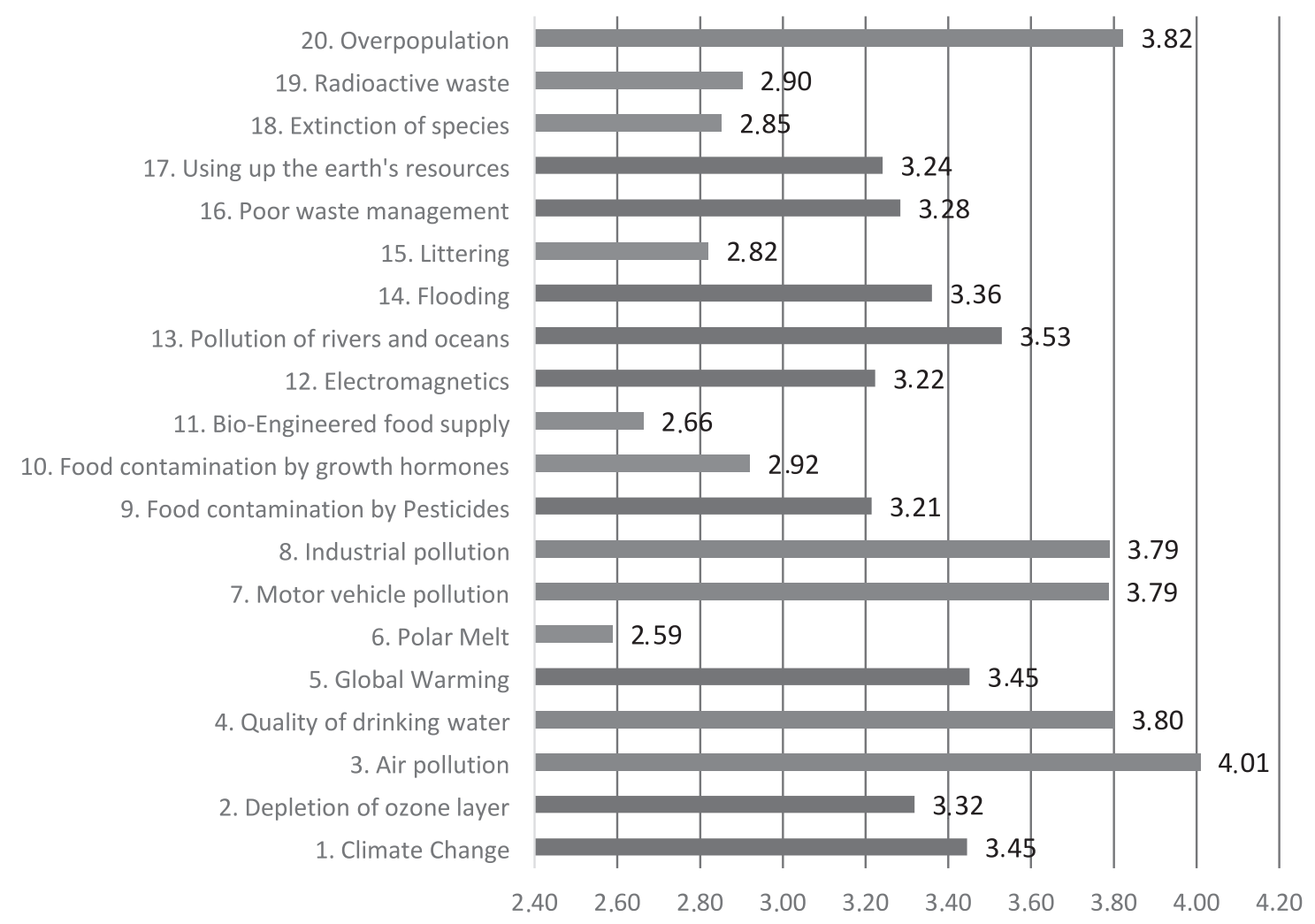

Fig. 1. Mean environmental awareness of university students. We used five points Likert scale with $1=$ no information, $2=$ little information, 3 = medium level information, $4=$ sufficient information, and $5=$ complete information. The mean of the scale is 3 which indicates medium level information. Grand mean of the environmental awareness among the university students 3.30 was significantly higher than 3 (one-sample t-test; $t=13.39, p$-value $=0.000$ ). 
20. Overpopulation (of the earth by humans)

19. Radioactive waste

18. Extinction of species

17. Using up the earth's resources

16. Poor waste management (e.g. overuse of landfills)

15. Littering

13. Pollution of rivers and oceans

12. Electromagnetics (power lines, cell phones, etc.)

11. Bio-Engineered food supply

10. Food contamination by growth hormones and.

9. Food contamination by Pesticides

8. Industrial pollution

7. Motor vehicle pollution

6. Polar Melt

5. Global Warming

4. Quality of drinking water

3. Air pollution

2. Depletion of ozone layer

1. Climate Change

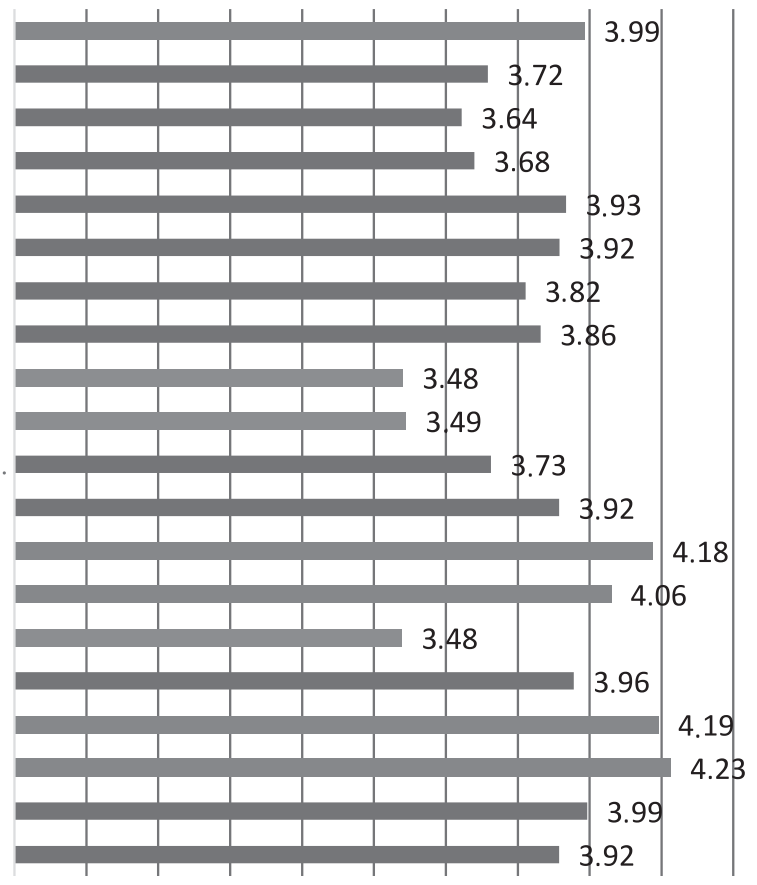

$\begin{array}{lllllllllll}2.40 & 2.60 & 2.80 & 3.00 & 3.20 & 3.40 & 3.60 & 3.80 & 4.00 & 4.20 & 4.40\end{array}$

Fig. 2. Mean environmental concern of university students. We used five points Likert scale with $1=$ no concern, $2=1$ low concern, $3=$ medium level concern, $4=$ high concern, and 5 = very high concern. Mean of the scale is 3 which indicates medium level concern. Grand mean of the environmental concern was significantly higher than 3 (one-sample t-test; $t=39.504$, $p$-value $=0.000$ ).

each statement ranging from $1-5$ indicating strongly disagree - strongly agree. The mean environmental attitude for three statements has been found as less than 3 , the mean of the scale (neutral i.e. neither disagree nor agree). A mean value less than 3 shows a tendency toward disagreeing the given statement. The statement "humans are not more important than animals" has mean 2.24, "people have no right to modify the natural environment to suit their needs" has 2.48, and "we should not rely on other people or the government to protect our environment" has mean of 2.85. Other statements have their means approximately equal to 3 or higher than 3 (Fig. 3). Grand mean of the environmental attitude 2.95 was significantly less than 3 (one-sample t-test; $t=-2.932, p$-value $=0.003)$. Environmental attitude across academic disciplines was significantly different

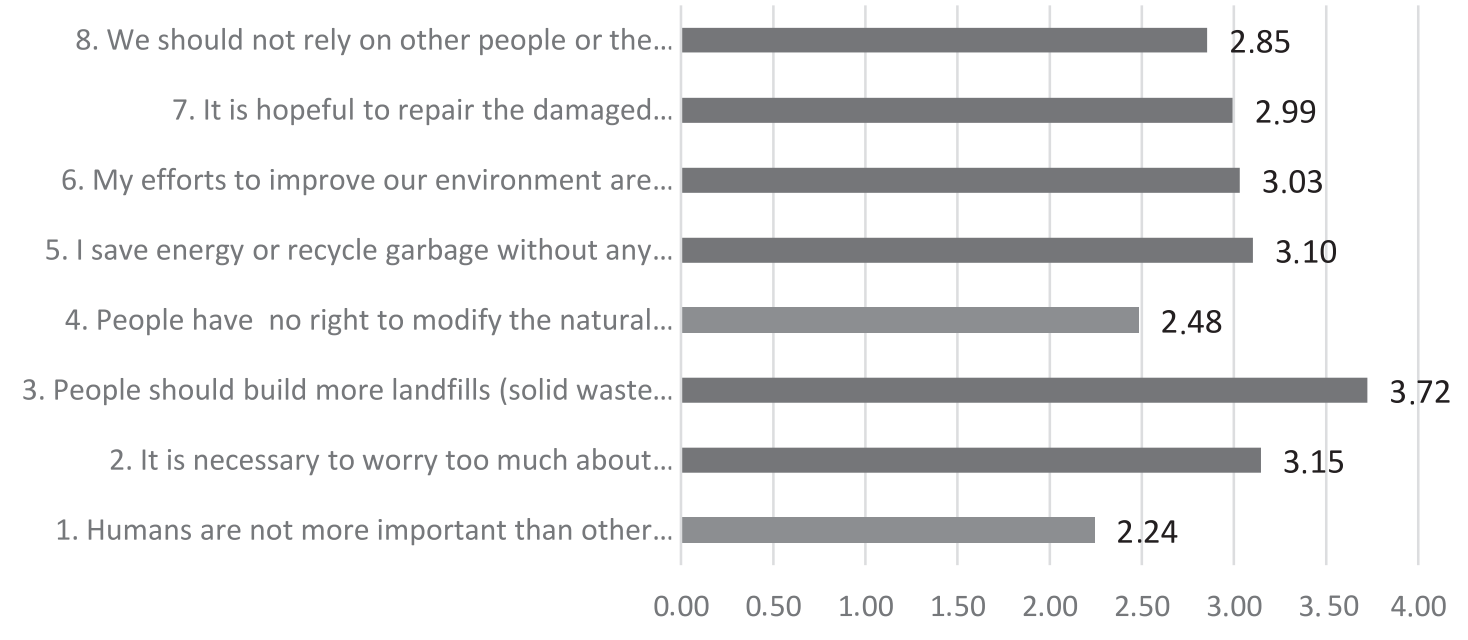

Fig. 3. Mean environmental attitude of university students. We used five points Likert scale with " $1=$ strongly disagree, 2 = disagree, 3 = neutral, 4 = agree, and $5=$ strongly agree". Mean of the scale is 3 (neutral i.e. neither disagree nor agree). Grand mean of the environmental attitude 2.95 was significantly less than 3 indicating the tendency toward disagree (one-sample t-test; $t=-2.932$, $p$-value $=0.003$ ). 
(ANOVA; $F=7.58, p$-value $=0.000)$. The students of biological sciences showed the highest level of attitude (mean 3.07), followed by physical sciences (mean 3.02), environmental sciences (mean 2.97), social sciences (mean 2.91), and arts \& humanities (mean 2.77).

\section{Environmental Behavior of University Students}

Environmental behavior has much importance with respect to fighting against environmental issues being faced by the globe. The environmental behavior of university students was measured with the help of a scale consisting of 12 actions. The students were asked to respond to any one of the five options viz; "1 = never", "2 = hardly ever", "3 = sometimes", "4 = usually", and "5 = always". Mean environmental behavior for three statements/ actions was found very discouraging because it was less than 3 (the mean of the scale i.e. "I have done for sometimes"). These statements were "How often did you prepare your own drinking water instead of buying bottled water?" with mean behavior of 2.79, "How often did you recycle trash?" with mean behavior of 2.84 and "How often did you collect reusable products (cups, containers or bags)?" with mean of 2.95. All other actions were having mean behavior within the range of 3.13 and 3.75 except of the one "How often did you turn off the lights and fans when you left a room?" having the mean behavior of 4 (Fig. 4). Grand mean of the environmental behavior 3.36 was significantly higher than 3 (one-sample t-test; $t=18.718, p$-value $=0.000)$. Environmental behavior across academic disciplines was significantly different (ANOVA; $F=8.89, p$-value $=0.000$ ). The students of biological sciences showed highest level of environmental behavior (mean 3.52), followed by environmental sciences and arts \& humanities (mean
3.41), physical sciences (mean 3.37), and social sciences (mean 3.19).

\section{Impact of Environmental Variables on Environmental Behavior}

In order to analyze the association between environmental behavior (EB) and the influential variables i.e. environmental awareness (EA), environmental concern (EC) and environmental attitude (Eatt), multiple regression was applied. Environmental behavior significantly depended on these environmental variables (multiple regression; $\mathrm{R}^{2}=0.21, \mathrm{~F}=71.40$, $p$-value $=0.000)$. When we consider the effects of individual variables, the values of regression coefficients for EA, EC and Eatt were $0.247(\mathrm{t}=9.539$, $p$-value $=0.000), 0.178(\mathrm{t}=-2.806, p$-value $=0.000)$, and $-0.092(\mathrm{t}=5.993$, $p$-value $=0.005)$ respectively. Out of these, EA and EC have positive significant effects, whereas, Eatt has a negative significant effect on the environmental behavior of the university students. The value of constant for the estimated regression model is $2.036(\mathrm{t}=13.368$, $p$-value $=0.000)$ which is also significant and provides the mean value of the environmental behavior of university students when the effects of all the independent variables are assumed to be zero.

\section{Discussion}

The results of this study show that the level of environmental awareness regarding six (out of 20) issues was found very low, however, for all others, it was found above medium level. Grand mean (3.30) was found significantly above the medium level.

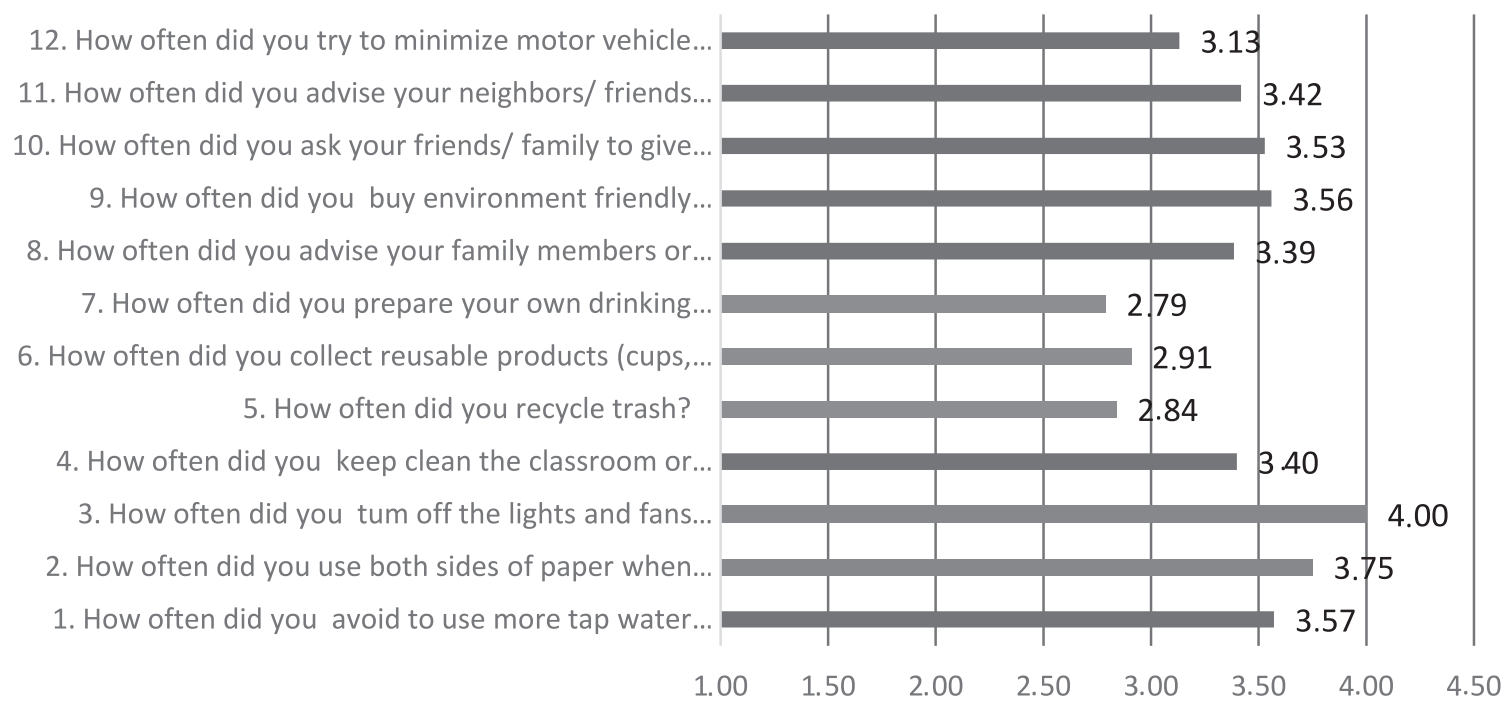

Fig. 4. Mean environmental behavior of university students. We used five points Likert scale with $1=$ never, $2=$ hardly ever, 3 sometimes, $4=$ usually, and $5=$ always. Mean of the scale is 3 (which indicates that respondent did a respective action for sometimes). Grand mean of the environmental behavior 3.36 was significantly higher than 3 (one-sample t-test; $t=18.718, p$-value $=0.000$ ). 
Mean environmental behavior (3.36) of university students was also observed as significantly high. As regards the impact of environmental awareness on environmental behavior, it was observed as positive and significant. These results conform with several studies that have measured the environmental awareness and environmental behavior of different groups of society. Altin, Tecer [29] measured the environmental awareness of students of secondary schools in Turkey and declared that those students have a high level of environmental awareness. Similarly, Vicente-Molina, Fernández-Sáinz [50] measured the effect of environmental knowledge on the pro-environmental behavior for university students of developing countries and advanced countries and found it positive and significant. Huang and Yore [39] conducted a study for school students of Canada and Taiwan and declared that the level of environmental knowledge was moderate and its impact on environmental behavior was significant. Similar results were also found by Gabarda-Mallorqui, Fraguell [33], and Ari and Yilmaz [25]. Some other studies like Alp, Ertepinar [51] have also studied the impact of environmental awareness on environmental behavior, however, they have reported this impact as insignificant.

The situation of environmental concern of university students was very much encouraging. Mean environmental concern for five issues was ranked as high concern, whereas, for others, it was above medium level. Grand mean of environmental concern (3.86) was significantly higher than the medium level, as well as, its impact on environmental behavior was positive and significant. These results also conform with the results of several researches conducted in this field. For example, Huang and Yore [39] studied the environmental concern of Candaian and Taiwanees school students and found that their levels of environmental concern and environmental behavior were very high, and impact of environmental concern on environmental behavior was also significant. Similarly, Iversen and Rundmo [52] rn on environmental behavior was also significant. Similarly, Iversen and Rundmo [52] have studied the impact of environmental concern, along with some other variables, on environmental behavior and found it positive and significant. Similar results were also found by Gkargkavouzi, Halkos [53], $\mathrm{Ha}$ and Kwon [54] and Steg, Bolderdijk [55].

The situation of the environmental attitude of university students was not encouraging. We found its mean (2.95) very low, as well as, it has a significantly negative impact on environmental behavior. These results partially conform with some studies indicating the low level of attitude among the different groups of society [30, 31], however, several other studies show different results. For example, Huang and Yore [39], and Paço and Lavrador [56] have reported positive environmental attitudes of different groups of the population, but insignificant impact on environmental behavior. On the other hand, some authors like Tian, Zhang [57], Gao [35] and Zheng, Wang [36] have reported this impact as significant. Boiyo, Koech [37] have also reported similar results for university students of Kenya. Kaiser, Wölfing [40] have reported significant impact of environmental attitude on the environmental behavior of people by considering the situations when it bcomes out of control to behave ecologically.

As regards the comparison across five academic disciplines, all of the five mean levels of environmental awareness of university students were found higher than the medium level awareness. The students of social sciences remained the lowest of all with mean of 3.09. The students of biological sciences won first position with a mean value of 3.69 , whereas, students of environmental sciences remained at second position with a mean value of 3.42. Mean levels of environmental concern for all the disciplines were also found high with the social sciences as the lowest with a mean value of 3.69 and biological sciences as the highest of all with a mean value of 4.14. As regards the environmental attitude, students of three disciplines remained very low: arts \& humanities (2.77), social sciences (2.91) and environmental sciences (2.97). The mean environmental attitude of the students of physical sciences and biological sciences were 3.02 and 3.07 respectively. The mean levels of the environmental behavior of students of all the five disciplines were found very high. The students of social sciences remained the lowest of all with a mean value of 3.19, and of biological sciences remained the highest of them with a mean value of 3.52 . Very limited literature discusses the comparisons among the individuals based on their academic disciplines. Benton Jr [58] has discussed the environmental knowledge, attitude, concern and behavior of business and non-business students, and reported that business students do not have less knowledge, but less environmental concern, attitude and behavior. Müderrisoglu and Altanlar [59] have studied environmental attitude and behavior of undergraduate students enrolled in different faculties like faculty of economics, faculty of medicine, faculty of technical education, faculty of education, and faculty of arts and science etc. They have investigated different aspects of attitude (ecocentric, technocentric and dualcentric) and behavior (activism, consumerisms and recycling) of the respondents. They found significant differences for two aspects of behavior i.e. activism and recycling, but insignificant for all others. Wong [45] has also studied the environmental awareness and consciousness of Chinese university students. He collected the data from the students of different academic disciplines like arts, sciences, agriculture, engineering etc. however, results are shown upto aggregate level. The author of this study reports high consciousness of university students about the environmental issues being faced by the people in the country and worldwide. 


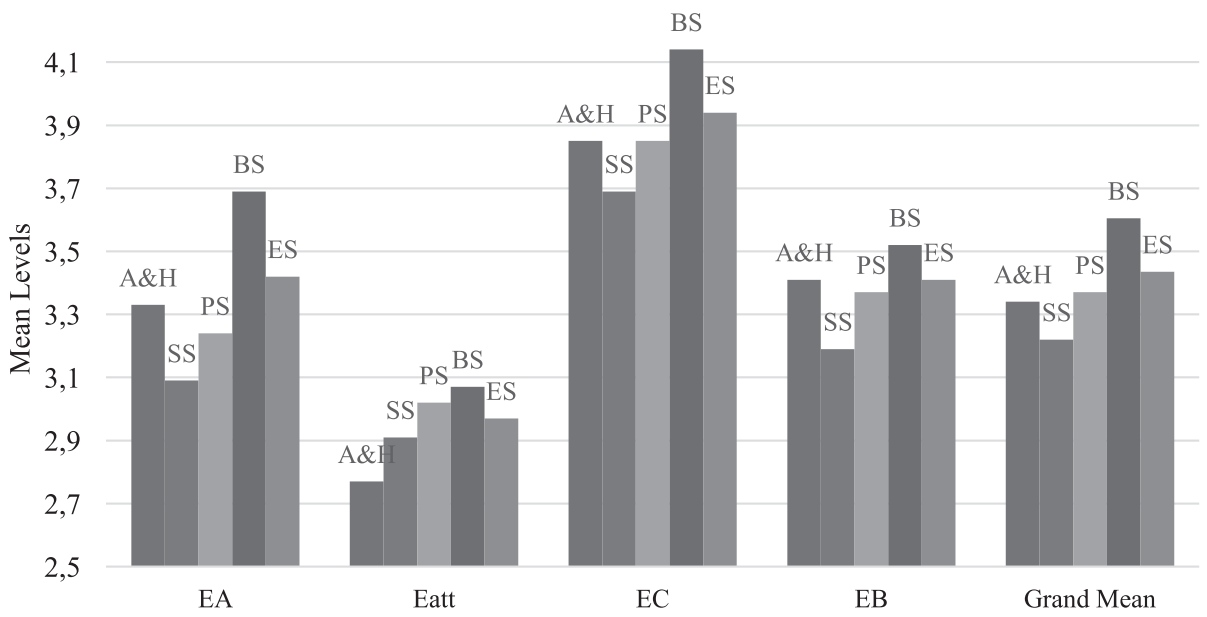

Fig. 5. Comparitive mean levels of environmental variables across academic disciplines. Grand mean is the mean of all means of EA, Eatt, EC and EB for each academic discipline. According to this criterion, group of biological sciences remaind at top, followed by environmental sciences, physical sciences, arts \& humanities and social sciences.

\section{Conclusion}

On the basis of the results and discussion made in the aforementioned sections, it is concluded that university students possess high levels of environmental awareness, environmental concern and environmental behavior, but very low level of environmental attitude. Environmental awareness and environmental concern of university students contribute positively in shaping their environmental behavior, however, environmental attitude contributes negatively. There are significant differences among the students of five academic disciplines (arts \& humanities, social sciences, physical sciences, biological sciences and environmental sciences) regarding their levels of environmental awareness, concern, attitude and behavior. Biological sciences were ranked at top in all cases of EA, Eatt, EC and EB. Environmental sciences remained at second position in majority of the cases, physical sciences at third, arts \& humanities at fourth and social sciences remained at last position in majority of the cases. Comparative view of mean levels of environmental variables across the academic disciplines is presented in the Fig. 5.

\section{Acknowledgements}

This work is part of the MS thesis of Sajida Shafi. The authors are very much thankful to all colleagues and evaluators for their valuable contributions to the improvement of this work.

\section{Conflict of Interest}

The authors would like to declare that they have no conflict of interest in the publication of this research work.

\section{References}

1. SATAPATHY S., PANDA C.R. Source identification, environmental risk assessment and human health risks associated with toxic elements present in a coastal industrial environment, India. Environ. Geochem. Health, 40 (6), 2243, 2018.

2. SHAHID N., ZIA Z., SHAHID M., FAIQ BAKHAT H., ANWAR S., MUSTAFA SHAH G., RIZWAN ASHRAF M. Assessing Drinking Water Quality in Punjab, Pakistan. Pol. J. Environ. Stud., 24 (6), 2597, 2015.

3. BEKETOV M.A., KEFFORD B.J., SCHÄFER R.B., LIESS M. Pesticides reduce regional biodiversity of stream invertebrates. Proc. Natl. Acad. Sci., 110 (27), 11039, 2013.

4. GOUDARZI G., ALAVI N., GERAVANDI S., IDANI E., BEHROOZ H.R.A., BABAEI A.A., ALAMDARI F.A., DOBARADARAN S., FARHADI M., MOHAMMADI M.J. Health risk assessment on human exposed to heavy metals in the ambient air PM10 in Ahvaz, southwest Iran. Int. J. Biometeorol., 62 (6), 1075, 2018.

5. SHAHID N., BECKER J.M., KRAUSS M., BRACK W., LIESS M. Adaptation of Gammarus pulex to agricultural insecticide contamination in streams. Sci. Total Environ., 621, 479, 2018.

6. LELIEVELD J., EVANS J.S., FNAIS M., GIANNADAKI D., POZZER A. The contribution of outdoor air pollution sources to premature mortality on a global scale. Nature, 525 (7569), 367, 2015.

7. LAKHERWAL D. Adsorption of heavy metals: A review. Int. J. Env. Res. Dev., 4 (1), 41, 2014.

8. COHEN A.J., BRAUER M., BURNETT R., ANDERSON H.R., FROSTAD J., ESTEP K., BALAKRISHNAN K., BRUNEKREEF B., DANDONA L., DANDONA R. Estimates and 25-year trends of the global burden of disease attributable to ambient air pollution: An analysis of data from the Global Burden of Diseases Study 2015. The Lancet, 389 (10082), 1907, 2017.

9. HAMRA G.B., GUHA N., COHEN A., LADEN F., RAASCHOU-NIELSEN O., SAMET J.M., VINEIS P., FORASTIERE F., SALDIVA P., YORIFUJI T. Outdoor particulate matter exposure and lung cancer: A systematic review and meta-analysis. Environ. Health Perspect., 122 (9), 906, 2014. 
10. PRÜSS-ÜSTÜN A., NEIRA M., Preventing disease through healthy environments: a global assessment of the burden of disease from environmental risks. World Health Organization, 2016.

11. ROSI-MARSHALL E., SNOW D., BARTELT-HUNT S., PASPALOF A., TANK J. A review of ecological effects and environmental fate of illicit drugs in aquatic ecosystems. J. Hazard. Mater., 282

12. HADDAD N.M., BRUDVIG L.A., CLOBERT J., DAVIES K.F., GONZALEZ A., HOLT R.D., LOVEJOY T.E., SEXTON J.O., AUSTIN M.P., COLLINS C.D. Habitat fragmentation and its lasting impact on Earth's ecosystems. Sci. Advanc., 1 (2), e1500052, 2015.

13. TISON L., HAHN M.-L., HOLTZ S., RÖßNER A., GREGGERS U., BISCHOFF G., MENZEL R. Honey bees' behavior is impaired by chronic exposure to the neonicotinoid thiacloprid in the field. Environ. Sci. Technol., 50 (13), 7218, 2016.

14. BAUDY P., ZUBROD J.P., KONSCHAK M., WEIL M., SCHULZ R., BUNDSCHUH M. Does long-term fungicide exposure affect the reproductive performance of leaf-shredders? A partial life-cycle study using Hyalella azteca. Environ. Pollut., 222, 458, 2017.

15. IPPOLITO A., KATTWINKEL M., RASMUSSEN J.J., SCHÄFER R.B., FORNAROLI R., LIESS M. Modeling global distribution of agricultural insecticides in surface waters. Environ. Pollut., 198, 54, 2015.

16. MACKINTOSH T.J., DAVIS J.A., THOMPSON R.M. Impacts of multiple stressors on ecosystem function: leaf decomposition in constructed urban wetlands. Environ. Pollut., 208, 221, 2016.

17. BACKHAUS T., BRACK W., VAN DEN BRINK P.J., DEUTSCHMANN B., HOLLERT H., POSTHUMA L., SEGNER H., SEILER T.-B., TEODOROVIC I., FOCKS A. Assessing the ecological impact of chemical pollution on aquatic ecosystems requires the systematic exploration and evaluation of four lines of evidence. Environ. Sci. Europ., 31 (1), 1, 2019.

18. SIDDIQUE A., LIESS M., SHAHID N., BECKER J.M. Insecticides in agricultural streams exert pressure for adaptation but impair performance in Gammarus pulex at regulatory acceptable concentrations. Sci. Total Environ., 722, 137750, 2020.

19. PREETI J.K.R., THAKUR M., SUMAN M., KUMAR R. Consequences of pollution in wildlife: A review. Pharm. Innov. J., 7 (4), 94, 2018.

20. STUART-SMITH S.J., JEPSON P.D. Persistent threats need persistent counteraction: Responding to $\mathrm{PCB}$ pollution in marine mammals. Mar. Policy, 84, 69, 2017.

21. BENDOR T., LESTER T.W., LIVENGOOD A., DAVIS A., YONAVJAK L. Estimating the size and impact of the ecological restoration economy. PLoS One, 10 (6), 2015.

22. IFTEKHAR M.S., POLYAKOV M., ANSELL D., GIBSON F., KAY G.M. How economics can further the success of ecological restoration. Conserv. Biol., 31 (2), 261, 2017.

23. MIDDEN C.J., KAISER F.G., TEDDY MCCALLEY L. Technology's four roles in understanding individuals' conservation of natural resources. J. Soc. Iss., 63 (1), 155, 2007.

24. STEG L., VLEK C. Encouraging pro-environmental behaviour: An integrative review and research agenda. J. Environ. Psychol., 29 (3), 309, 2009.

25. ARI E., YILMAZ V. Effects of environmental illiteracy and environmental awareness among middle school students on environmental behavior. Environ. Dev. Sustainability, 19 (5), 1779, 2017.

26. GEIGER S.M., DOMBOIS C., FUNKE J. The role of environmental knowledge and attitude: Predictors for ecological behavior across cultures. An analysis of Argentinean and German students. . Umweltpsychologie, 22, 69, 2018.

27. GEMET. Environmental awareness. 2019 [cited 201916 November]; Available from: https://www.eionet.europa.eu/ gemet/en/concept/2778, 2019.

28. KARATEKIN K. Social studies pre-service teachers' awareness of solid waste and recycling. Procedia Soc. Behav. Sci., 116, 1797, 2014.

29. ALTIN A., TECER S., TECER L., ALTIN S., KAHRAMAN B.F. Environmental awareness level of secondary school students: A case study in Balıkesir (Türkiye). Procedia Soc. Behav. Sci., 141, 1208, 2014.

30. HAUSBECK K.W., MILBRATH L.W., ENRIGHT S.M. Environmental knowledge, awareness and concern among 11th-grade students: New York State. J. Environ. Educ., 24 (1), 27, 1992.

31. MANSARAY A., AJIBOYE J., AUDU U. Environmental knowledge and attitudes of some Nigerian secondary school teachers. Environ. Educ. Resear., 4 (3), 329, 1998.

32. OĞUZ D., ÇAKCI I., KAVAS S. Environmental awareness of university students in Ankara, Turkey. Afri. J. Agri. Res., 5 (19), 2629, 2010.

33. GABARDA-MALLORQUI A., FRAGUELL R.M., RIBAS A. Exploring Environmental Awareness and Behavior among Guests at Hotels That Apply WaterSaving Measures. Sustainability, 10 (5), 1305, 2018.

34. KUHLEMEIER H., VAN DEN BERGH H., LAGERWEIJ N. Environmental knowledge, attitudes, and behavior in Dutch secondary education. J. Environ. Educ., 30 (2), 4, 1999.

35. GAO Y.F. To Study the Relationship between Environmental Education and Environmental Behavior Based on Environmental Attitude. Ekoloji, 27 (106), 627, 2018.

36. ZHENG W.-L., WANG J.-W., ZHANG X. Effects of Environmental Cognition and Environmental Attitude on Environmental Behavior of Ecotourism. Ekoloji, 27 (106), 1743, 2018.

37. BOIYO V., KOECH M., MANGURIU D. Environmental Attitudes and Ecological Behaviour among Students: A Case Study of Kibera and Kasarani Division in Nairobi, Kenya. Int. J. Interdiscip. Res. Innov., 3 (1), 50, 2015.

38. LO-IACONO-FERREIRA V., BAHR K., TORREGROSALÓPEZ J.I., NAKAGAWA M., Assessment Tool for Environmental Attitude of Students in Higher Education Institutions in 21th International Congress on Project Management and Engineering Cádiz, 12 ${ }^{\text {th }}-14^{\text {th }}$ July 2017.

39. HUANG H.-P., YORE L.D. A comparative study of Canadian and Taiwanese grade 5 children's environmental behaviors, attitudes, concerns, emotional dispositions, and knowledge. Int. J. Sci. Math. Educ., 1 (4), 419, 2005.

40. KAISER F.G., WÖLFING S., FUHRER U. Environmental attitude and ecological behaviour. J. Environ. Psychol., 19 (1), 1,1999

41. ONUR A., SAHIN E., TEKKAYA C. An investigation on value orientations, attitudes and concern towards the environment: the case of Turkish elementary school students. Environ. Educ. Resear., 18 (2), 271, 2012.

42. DIEKMANN A., FRANZEN A., Environmental concern: A global perspective, in Einstellungen und 
Verhalten in der empirischen Sozialforschung, Springer. 253, 2019.

43. BONNETT M., WILLIAMS J. Environmental education and primary children's attitudes towards nature and the environment. Camb. J. Educ., 28 (2), 159, 1998.

44. MCKENZIE-MOHR D., NEMIROFF L.S., BEERS L., DESMARAIS S. Determinants of responsible environmental behavior. J. Soc. Iss., 51 (4), 139, 1995.

45. WONG K.-K. The environmental awareness of university students in Beijing, China. J. Contemp. China, 12 (36), 519, 2003.

46. RAOSOFT. Sample Size Calculator. 2019 [cited 2019 31 January]; Available from: http://www.raosoft.com/ samplesize.html, 2019.

47. DONOHOE M. Causes and health consequences of environmental degradation and social injustice. Soc. Sci. Med., 56 (3), 573, 2003.

48. HARRIS F. Global environmental issues. John Wiley \& Sons, 2012

49. JIANPING L., MINRONG L., JINNAN W., JIANJIAN L., HONGWEN S., MAOXING H., Global Environmental Issues and Human Wellbeing, in Report on Global Environmental Competitiveness (2013), L. Jianping, et al., Editors, Springer Berlin Heidelberg: Berlin, Heidelberg. p. 3, 2014.

50. VICENTE-MOLINA M.A., FERNÁNDEZ-SÁINZ A., IZAGIRRE-OLAIZOLA J. Environmental knowledge and other variables affecting pro-environmental behaviour: comparison of university students from emerging and advanced countries. J. Clean. Prod., 61, 130, 2013.

51. ALP E., ERTEPINAR H., TEKKAYA C., YILMAZ A. A statistical analysis of children's environmental knowledge and attitudes in Turkey. Int. Res. Geogr. Environ. Educ., 15 (3), 210, 2006.

52. IVERSEN H., RUNDMO T. Environmental concern and environmental behaviour among the Norwegian public. J. Risk Res., 5 (3), 265, 2002.

53. GKARGKAVOUZI A., HALKOS G., MATSIORI S. A Multi-dimensional Measure of Environmental Behavior: Exploring the Predictive Power of Connectedness to Nature, Ecological Worldview and Environmental Concern. Soc. Indic. Res., 143 (2), 859, 2019.

54. HA S.J., KWON S. Spillover from past recycling to green apparel shopping behavior: the role of environmental concern and anticipated guilt. Fash. Text., 3 (1), 16, 2016.

55. STEG L., BOLDERDIJK J.W., KEIZER K., PERLAVICIUTE G. An integrated framework for encouraging pro-environmental behaviour: The role of values, situational factors and goals. J. Environ. Psychol., 38, 104, 2014.

56. PAÇO A., LAVRADOR T. Environmental knowledge and attitudes and behaviours towards energy consumption. J. Environ. Manage., 197, 384, 2017.

57. TIAN H.R., ZHANG J., LI J.J. The relationship between pro-environmental attitude and employee green behavior: the role of motivational states and green work climate perceptions. Environ. Sci. Pollut. Res., 27, 7341, 2019.

58. BENTON JR R. Environmental knowledge and attitudes of undergraduate business students compared to nonbusiness students. Bus. Soc., 33(2), 191, 1994.

59. MÜDERRISOGLU H., ALTANLAR A. Attitudes and behaviors of undergraduate students toward environmental issues. Int. J. Environ. Sci. Technol. (Tehran), 8(1), 159, 2011. 